Nurhidayati, et al/Jurnal Ekonomi Syariah Teori dan Terapan Vol. 6 No. 2 Februari 2019: 214-227; PENGARUH FAKTOR MAKROEKONOMI DAN FAKTOR FUNDAMENTAL TERHADAP RETURN SAHAM PERUSAHAAN YANG LISTING DI JAKARTA ISLAMIC INDEX PERIODE 2012-2016

\title{
PENGARUH FAKTOR MAKROEKONOMI DAN FAKTOR FUNDAMENTAL TERHADAP RETURN SAHAM PERUSAHAAN YANG LISTING DI JAKARTA ISLAMIC INDEX PERIODE 2012-2016
}

\author{
Hanifa Nurhidayati \\ Departemen Ekonomi Syariah- Fakultas Ekonomi dan Bisnis-Universitas Airlangga \\ Email: hanifa-nu-11@feb.unair.ac.id

\section{Ari Prasetya} \\ Departemen Ekonomi Syariah- Fakultas Ekonomi dan Bisnis-Universitas Airlangga \\ Email: ari_p@feb.unair.ac.id
}

\begin{abstract}
:
The goal of this research is to determine the effect of corporate Macroeconomics Factor and Fundamental Factor on Stock Return of Listed Companies in the Jakarta Islamic Index (JII) partially or simultaneously. The research method used is the quantitative approach. The research sample is 20 companies registered in $\mathrm{Jll}$ that meet the criteria of purposive sampling. The analysis technique used best estimation model by Common Effect Model (CEM) and the result is $Y=3,190398+0,0013$ Inflasilit $+0,0001$ BiRate $_{\text {it }}+0,0341$ GDP $_{\text {it }}-0,1246$ EPS $_{\text {it }}$ $+0,000 D E R_{t}+0,1744 C R_{t}$ and $R^{2} 24,24 \%$. The result of the partial test shows that Inflation and Return On Equity ratio have a significant effect. The result of the simultaneous test shows that the four variables have significant effects on stock return of companies registered in JII.
\end{abstract}

Keywords: Return Stock, Current Ratio, Return On Equity, Earning Per Share, Debt to Equity Ratio, GDP, Bi Rate, Inflation, Jakarta Islamic Index.

\section{PENDAHULUAN}

\section{LATAR BELAKANG}

Sekarang ini, kegiatan berinvestasi di Indonesia sedang memarak bahkan diseluruh dunia. Salah satunya adalah di pasar modal. Didalam Islam menganjurkan di dalam hidupnya, manusia untuk menginvestasikan hartanya pada prinsip-prinsip Islam yang ada. Pasar modal adalah peranan sangat penting dalam perekonomian, hal ini dikarenakan pasar modal menjalankan fungsi ekonomi sekaligus fungsi keuangan. Perkembangan pasar modal juga menjadi indikator sumber dan salah satu alternatif pendanaan selain bank. Maraknya investasi di pasar modal mengakibatkan meningkatnya jumlah investor yang beralih dari sektor perbankan ke dalam sektor pasar modal. Di satu sisi, terdapat pasar modal syariah yaitu sejumlah instrumen kevangan yang ditawarkan pada investor berinvestasi dimana juga memenuhi ketentuan syariah.

Langkah awal perkembangan pasar modal syariah di Indonesia dimulai dengan diterbitkannya reksadana syariah pada 25 Juni 1997 diikuti dengan diterbitkannya obligasi syariah pada akhir 2002. Selanjutnya, pada bulan Juli 2000 PT Bursa Efek Jakarta (BEJ) bersama dengan PT Dana Reksa Invesment Management (DIM) menerbitkan Jakarta Islamic Index (JII) yang terdiri dari 30 (tiga puluh) jenis saham dari emiten-emiten yang kegiatan usahanya memenuhi syariah Islam. Penentuan kriteria dari komponen Jakarta Islamic Index (JII) tersebut disusun berdasarkan persetujuan dari Dewan

1) Jurnal ini merupakan bagian dari skripsi Hanifa Nurhidayati, NIM: 041114024, yang diuji pada tanggal 12 Juli 2018. 
Nurhidayati, et al/Jurnal Ekonomi Syariah Teori dan Terapan Vol. 6 No. 2 Februari 2019: 214-227;

PENGARUH FAKTOR MAKROEKONOMI DAN FAKTOR FUNDAMENTAL TERHADAP RETURN SAHAM PERUSAHAAN YANG LISTING DI JAKARTA ISLAMIC INDEX PERIODE 2012-2016

Pengawas Syariah DIM (Dana Reksa Invesment Manajement).

Adanya perkembangan pasar modal syariah yang pesat ini, maka banyak investor yang ingin mendapatkan return saham melalui penanaman modal yang telah dilakukannya. Menurut Wijayanti (2003) banyak macam pilihan investasi yang dapat dilakukan di pasar modal meliputi investasi saham syariah, investasi non-syariah dan gabungan keduanya. Dari macam-macam saham investasi harus melakukan investasi portofolio mana yang menghasilkan return saham atau pengembalian yang diinginkan.

$$
\text { Return saham merupakan }
$$
keuntungan yang akan di dapatkan oleh investor dari kegiatan investasinya. Bagi investor tinggi rendah return merupakan tolak ukur penialian pembagian hasil suatu saham. Return saham dipengaruhi oleh beberapa faktor, yaitu faktor eksternal / makroekonomi (Inflasi, bi rate, dan gdp) dan faktor internal / fundamental (Earning Per Share, Debt to Equity Ratio, Current Ratio dan Return On Equity).

Dengan mengetahui faktor-faktor makro dan fakto fundamental yang dapat mempengaruhi return saham perusahaan, analisis makro ekonomi dan fundamental juga sering disebut analisis perusahaan karena dapat menggunakan data laporan kevangan dalam menghitung nilai intrinsik perusahaan. Salah satu teknik dalam analisa laporan keuangan adalah analisis rasio keuangan.
Berdasarkan hasil uraian diatas dalam latar belakang permasalahan dan hasil penelitian terdahulu yang lebih bervariasi, sulit untuk mendeteksi seberapa besar kemampuan variabel bebas dari faktormakroekonomi dan faktor fundamental dalam menjelaskan pengaruh tingkat pengembalian atau return saham. Hal tersebut memberikan peluang untuk melakukan penelitian lanjutan, untuk menguji konsistensi hasil penelitian sebelumnya dan memperoleh bukti empiris ada tidaknya pengaruh faktor makroekonomi dan faktor fundamental perusahaan terhadap return saham.

\section{Rumusan Masalah}

Berdasarkan uraian latar belakang diatas, maka rumusan masalah yang dapat diajukan pada penelitian ini ad alah

1. Apakah Inflasi berpengaruh secara parsial terhadap return saham perusahaan yang listing di Jakarta Islamic Index?

2. Apakah Bi Rate berpengaruh secara parsial terhadap return saham perusahaan yang listing di Jakarta Islamic Index?

3. Apakah Gross Domestic Product berpengaruh secara parsial terhadap return saham perusahaan yang listing di Jakarta Islamic Index?

4. Apakah Earning Per Share berpengaruh secara parsial terhadap return saham 
Nurhidayati, et al/Jurnal Ekonomi Syariah Teori dan Terapan Vol. 6 No. 2 Februari 2019: 214-227; PENGARUH FAKTOR MAKROEKONOMI DAN FAKTOR FUNDAMENTAL TERHADAP RETURN SAHAM PERUSAHAAN YANG LISTING DI JAKARTA ISLAMIC INDEX PERIODE 2012-2016

perusahaan yang listing di Jakarta Islamic Index?

5. Apakah Current Ratio berpengaruh secara parsial terhadap return saham perusahaan yang listing di Jakarta Islamic Index?

6. Apakah Debt to Equity berpengaruh secara simultan terhadap return saham perusahaan yang listing di Jakarta Islamic Index?

7. Apakah Return On Equity berpengaruh secara simultan terhadap return saham perusahaan yang listing di Jakarta Islamic Index?

8. Apakah Inflasi, Bi Rate, GDP, Earning Per Share, Current Ratio, Debt to Equity dan Return On Equity berpengaruh secara simultan terhadap return saham perusahaan yang listing di Jakarta Islamic Index?

\section{Tujuan Penelitian}

Penelitian ini bertujuan untuk menjawab rumusan masalah yaitu untuk mengetahui apakah Inflasi, Bi Rate, Gross Domestic Product(GDP), Earning Per Share (EPS), Current Ratio (CR), Debt to Equity Ratio (DER), dan Return On Equity Ratio (ROE) berpengaruh parsial dan simultan terhadap return saham perusahaan yang listing di Jakarta Islamic Index.

\section{LANDASAN PUSTAKA}

\section{Pasar Modal}

Menurut Susilo D (2009: 16) "Pada hakikatnya pasar modal merupakan wadah bertemunya pihak dari perusahaan membuuhkan dan dan pihak yangkelebihan dana (pemodal atau tempat transaksi instrumen keuangan (saham, obligasi, dan waran) jangka panjang yang jatuh temponya lebih dari satu tahun.

\section{Pasar Modal Syariah}

Menurut Suhartono dan Qudsi (2009:6) bahwa pasar modal syariah adalah pasar yang di dalamnya terdapat instrumen keuangan atau sekuritas jangka panjang yang dapat diperjualbelikan termasuk dalam bentuk hutang ataupun modal sendiri, baik yang di terbitkan oleh pemerintah atau perusahaan swasta dengan adanya ketentuan prinsip syariah.

\section{Jakarta Islamic Index}

Jakarta Islamic Index atau biasa disebut Jll adalah salah satu indeks saham yang ada di Indonesia yang menghitung index harga rata-rata saham untuk jenis saham-saham yang memenuhi kriteria syariah. Pembentukan JII tidak lepas dari kerja sama antara Pasar Modal Indonesia (dalam hal ini PT Bursa Efek Jakarta) dengan PT Danareksa Invesment Management (PT DIM). Pembentukan instrumen syariah ini untuk mendukung pembentukan Pasar Modal Syariah yang kemudian diluncurkan di Jakarta. Mekanisme Pasar Modal Syariah meniru pola serupa di Malaysia yang digabungkan dengan bursa konvensional seperti Bursa Efek Jakarta dan Bursa Efek Surabaya. Setiap periodenya, saham yang masuk Jll berjumlah 30 (tiga puluh) saham yang memenuhi kriteria syariah. JII 
Nurhidayati, et al/Jurnal Ekonomi Syariah Teori dan Terapan Vol. 6 No. 2 Februari 2019: 214-227; PENGARUH FAKTOR MAKROEKONOMI DAN FAKTOR FUNDAMENTAL TERHADAP RETURN SAHAM PERUSAHAAN YANG LISTING DI JAKARTA ISLAMIC INDEX PERIODE 2012-2016

menggunakan hari dasar tanggal 1 Januari 1995 dengan nilai dasar 100.

\section{Faktor Makroekonomi}

Makroekonomi merupakan studi mengenai perekonomian secara enyeluruh yang berarti menjelaskan mengenai peristiwa-peristiwa ekonomi dan memikirkan kebijakan-kebijakan yang tepat untuk meningkatkan kinerja ekonomi (Mankiw, 2004:14).

\section{Inflasi}

Inflasi merupakan kecenderungan dari kenaikan harga yang terjadi secara terus menerus. Kenaikan harga yang dimaksud tidak hanya untuk satu atau dua barang atau jasa melainkan keseluruhan, dalam artian kenaikan harga satu barang akan berdampak pada kenaikan harga barang atau jasa lain (Liauw, 2013).

\section{Bi Rate / Suku Bunga}

Menurut Boediono (1995:97), suku bunga merupakan suatu harga yang harus dibayar apabila terjadi pertukaran antara satu rupiah sekarang dan satu rupiah nanti. Pada kenaikan suku bunga yang tidak wajar akan menyulitkan dunia usaha untuk membayar beban bunga dan kewajiban.

\section{Gross Domestic Product (GDP)}

Menurut Herlambang (2002:22), PDB adalah total pendapatan yang dihasilkan dalam suatu negara, termasuk pendapatan orang asing yang bekerja di negara tersebut. PDB suatu negara sama dengan total pendapatan seluruh penduduk dalam perekonomian dan total pengeluaran atas barang dan jasa dalam perekonomian.

\section{Faktor Fundamental}

Faktor fundamental ialah teknik untuk dapat menganalisis saham pada kevangan mendasar dan fakta ekonomi pada perusahaan sebagai langkah dari penilaian harga saham perusahaan (Gumandi, 2011). Mempelajari tentang keuangan mendasar di perlukannya laporan keuangan atau annual report yang tersedia atau publikasi, untuk mengetahui rasio-rasio mana yang akan di analisis. Menurut Ang (1997) rasioterdiri atas 5 jenis yakni rasio likuiditas, rasio aktivitas, rasio retabilitas (profitabilitas), rasio solvabilitas dan rasio pasar. Faktor fundamental yang baik historisnya bagi invetsor merupakan hal yang paling utama untuk berinvestasi kelak. Apabila pada sebuah perusahaan baik tingkat kinerja keuangannya maka diharapkan harga saham meningkat dan akan memberikan laba (return) saham bagi investor. Sebab return saham yang tinggi ialah salah satu daya tarik investor untuk menanamkan dananya di pasar modal. Oleh karena itu, jikalau kemampuan perusahaan untuk menghasilkan keuntungan meningkat maka harga saham juga meningkat. Semakin tinggi return yang didapatkan, maka akan semakin baik pemilik posisi perusahaan.

\section{Earning Per Share (EPS)}

Earning per Share ialah ukuran penting untuk digunakan mengukur kinerja perusahaan. Menurut (Tandeilin, 2010:374) menjelaskan Earning per Share (EPS) dapat menujukkan besarnya keuntungan bersih perusahaan yang siap 
Nurhidayati, et al/Jurnal Ekonomi Syariah Teori dan Terapan Vol. 6 No. 2 Februari 2019: 214-227; PENGARUH FAKTOR MAKROEKONOMI DAN FAKTOR FUNDAMENTAL TERHADAP RETURN SAHAM PERUSAHAAN YANG LISTING DI JAKARTA ISLAMIC INDEX PERIODE 2012-2016

dibagikan paham perusahaan,. Pada besarnya EPS suatu perusahaan dapat diketahui dari informasi laporan keuangan perusahaan. Walaupun dalam beberapa perusahaan tidak mencatumkan besarnya EPS perusahaan bersangkutan, tetapi EPS bisa dihtung berdasarkan informasi laporan neraca dan laporan laba rugi.

\section{Debt to Equity Ratio (DER)}

Debt To Equity Ratio adalah rasio yang menunjukkan kemampuan perusahaan untuk memenuhi segala kewajiban finansialnya saat likuidasi termasuk kelompok dalam rasio Leverage. Menurut Brigham dan Hapenski (1997), setiap perusahaan harus menetapkan tarhet struktur modal, yaitu pada posisi keseimbangan biaya dan keuntungan marginal dari pendanaan dengan hutang, sebab pada posisi itu nilai perusahaan menjadi maksimum. Berdasarkan teori tersebut, menggunakan semakin banyak hutang berarti memperbesar risiko yang ditanggung pemegang saham (ekuitas) dan juga memperkecil tingkat pengembalian yang diharapkan, sehingga potensial mengurangi return saham.

\section{Current Ratio (CR)}

Current Ratio (CR) adalah suatu cara untuk menguji tingkat proteksi yang diperoleh pemberi pinjaman berpusat pada kredit jangka pendek yang diberikan kepada perusahaan untuk mendanai kegiatan operasional perusahaan (Helfert, 2002). CR yang rendah biasanya dianggap menunjukkan terjadinya masalah dalam likuidasi, sebaliknya current ratio yang terlalu tinggi juga kurang bagus, karena menunjukkan banyaknya dana menganggur yang pada akhirnya dapat mengurangi kemampuan perusahaan (Sawir, 2009)

\section{Return On Equity (ROE)}

Menurut Hery (2015) Return On Equity (ROE) atau disebut hasil pengembalian ekuitas merupakan rasio yang menunjukkan seberapa besar kontribusi pada pengembalian ekuitas dalam menciptakan laba bersih. Kemampuan rasio ROE yaitu mengukur kinerja perusahaan supaya medapatkan tingkat pengembalian perusahaan atau efektivas perusahaan di dalam memperoleh laba dan memanfaatkan ekuitas yang dimiliki oleh perusahaan.

\section{Return Saham}

Menurut Ang (1997), return saham merupakan tingkat laba yang dihasilkan dari pemegang saham yang melakukan investasi. Return saham mengharapkan seorang pemegang saham supaya menimbang-nimbang antara keuntungan aktual ataupun keuntungan yang diinginkan disediakan dari berbagai saham pada tingkatan pengembalian yang diharapkan tersebut. Menurut Jogiyanto (2003), menyatakan yakni terdapat dua unsur return total saham, yaitu capital gain dan yield. Return saham memiliki beberapa faktor apa saja yang dapat mempengaruhi return menurut Samsul (2006:200), saham melingkupi dua faktor yakni faktor makro/ eksternal dan faktor internal / fundamental. 
Nurhidayati, et al/Jurnal Ekonomi Syariah Teori dan Terapan Vol. 6 No. 2 Februari 2019: 214-227; PENGARUH FAKTOR MAKROEKONOMI DAN FAKTOR FUNDAMENTAL TERHADAP RETURN SAHAM PERUSAHAAN YANG LISTING DI JAKARTA ISLAMIC INDEX PERIODE 2012-2016

\section{HIPOTESIS}

1. Inflasi, Bi Rate, Gross Domestic Product(GDP), Earning Per Share (EPS), Current Ratio (CR), Debt to Equity Ratio (DER), dan Return On Equity Ratio (ROE) berpengaruh secara parsial return saham perusahaan di Jakarta Islamic Index.

2. Inflasi, Bi Rate, Gross Domestic Product(GDP), Earning Per Share (EPS), Current Ratio (CR), Debt to Equity Ratio (DER), dan Return On Equity Ratio (ROE) ), berpengaruh secara simultan terhadap risiko sistematis saham perusahaan di Jakarta Islamic Index.

\section{MODEL ANALISIS}

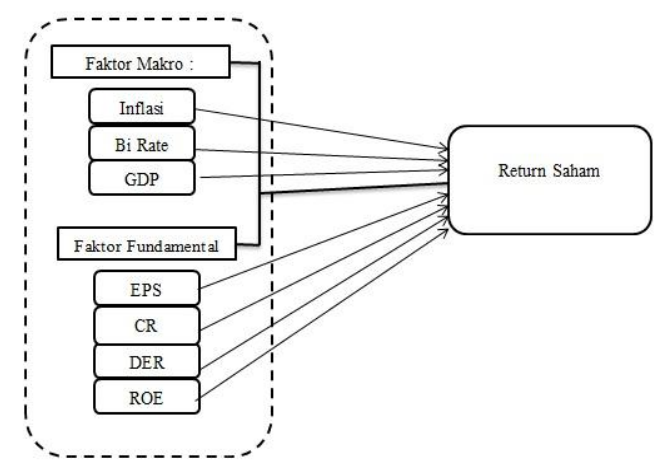

GAMBAR 1. MODEL ANALISIS

Model hubungan pembiayaan bermasalah dengan variabel-variabel tersebut dapat disusun dalam fungsi atau persamaan sebagai berikut:

$Y=a+b_{1} X_{1}+b_{2} X_{2}+b_{3} X_{3}+b_{4} X_{4}+b_{5} X_{5}+b_{6} X_{6}+b_{7} X_{7}$ $+e$

Dimana :

$\mathrm{Y}=$ Return Saham $\mathrm{a} \quad=$ Konstanta

$\mathrm{X}_{1} \quad=$ Inflasi

$\mathrm{X}_{2} \quad=$ Bi Rate

$\mathrm{X}_{3}=$ Growth Domestic Product

$\mathrm{X}_{4}=$ Earning Per Share

$\mathrm{X}_{5}=$ Current Ratio

$x_{6}=$ Debt to Equity Ratio

$X_{7}=$ Return On Equity

$\mathrm{e} \quad=$ error terms

\section{METODE PENELITIAN}

\section{RANCANGAN PENELITIAN}

Penelitian ini menggunakan rancangan penelitian berdasarkan pendekatan kuantitatif. Penelitian ini akan membuktikan pengaruh Inflasi, Bi Rate, Gross Domestic Product(GDP), Earning Per Share (EPS), Current Ratio (CR), Debt to Equity Ratio (DER), dan Return On Equity Ratio (ROE) terhadap return saham perusahaan yang listing di Jakarta Islamic Index..

\section{IDENTIFIKASI VARIABEL}

Variable bebas dalam penelitian ini adalah . Inflasi, Bi Rate, Gross Domestic Product(GDP), Earning Per Share (EPS), Current Ratio (CR), Debt to Equity Ratio (DER), dan Return On Equity Ratio (ROE) Sedangkan variabel terikatnya adalah terhadap return saham perusahaan di Jakarta Islamic Index.

\section{DEFINISI OPERASIONAL}

Variabel-variabel yang digunakan tersebut definisi operasionalnya adalah sebagai berikut:

1. Inflasi $\left(\mathrm{X}_{1}\right)$

Inflasi yaitu adanya tendensi dalam peningkatan harga secara menyeluruh yang sifatnya umu dan 
Nurhidayati, et al/Jurnal Ekonomi Syariah Teori dan Terapan Vol. 6 No. 2 Februari 2019: 214-227;

PENGARUH FAKTOR MAKROEKONOMI DAN FAKTOR FUNDAMENTAL TERHADAP RETURN SAHAM PERUSAHAAN YANG LISTING DI JAKARTA ISLAMIC INDEX PERIODE 2012-2016

terus-menerus. Inflasi ini dapat diperoleh dengan menggunakan rumus sebagai berikut:

$\Delta I F=\frac{I F_{t}-I F_{t-1}}{I F_{t-1}}$

2. Bi Rate $\left(\mathrm{X}_{2}\right)$

Bi Rate adalah presentasi dari pokok utang yang dibayarkan sebagai imbal jasa (bunga) dalam suatu periode tertentu. Pada sertifikat Bank Indonesia atau SBI yakni surat berharga yang dikeluarkan dari Bank Indonesia untuk penerimaan hutang berjangka waktu pendek (1-3 bulan)

$\Delta I R=\frac{I R_{t}-I R_{t-1}}{I R_{t-1}}$

3. Gross Domestic Product $\left(\mathrm{X}_{3}\right)$

Gross Domestic Product merupakan nilai pasa pada semua barang dan jasaakhir yang diproduksi oleh sebuah negara pada suatu periode. Gross Domestic Product dapat diperoleh dengan menggunakan rumus sebagai berikut:

$\triangle G D P=\frac{G D P_{t}-G D P_{t-1}}{G D P_{t-1}}$

4. Earning Per Share $\left(\mathrm{X}_{4}\right)$

Earning Per Share Ratio merupakan pembagian laba yang tersedia bagi para pemegang saham dengan ratarata tertimbang jumlah lembar saham yang beredar selama periode perhitungan dilakukan. Earning Per Share Ratio dapat diperoleh dengan rumus:

EPS $=\frac{\text { laba bersih setelah pajak }- \text { dividen saham preferen }}{\text { rata }- \text { rata jumlah saham beredar }}$

5. Current Ratio (X5)
Current Ratio merupakan rasio utnuk mengukur kemampuan perusahaan yang melakukan kewajiban membayar hutang jangka pendek atau segera jatuh tempo dengan aktiva lancar.

$C R=\frac{\text { Aktiva Lancar }}{\text { Hutang lancar }} \times 100 \%$

6. Debt to Equity Ratio $\left(X_{6}\right)$

Pengungkit (leverage) adalah suatu kebijakan yang dilakukan oleh suatu perusahaan dalam hal menginvestasikan dana atau memperoleh sumber dana yang disetrai dengan adanya beban atau biaya tetap yang harus ditanggung perusahaan.

Total Debt to Equity $=\frac{\text { Total Hutang }}{\text { Total ekuitas }}$

7. Return On Equity $\left(X_{7}\right)$

Return On Equity Ratio merupakan kemampuan perusahaan dalam menghasilkan laba bersih menggunakan ekuitasnya. Return On Equity dapat di peroleh menggunakan rumus:

$$
R O E=\frac{\text { Laba bersih setelah pajak }}{\text { Ekuitas }}
$$

8. Return Saham (Y)

Return saham merupakan keuangan yang diberikan kepada investor atas penanaman modal yang berupa capital gain (loss) dan dividend yield.

$R=\frac{P_{t}-P_{t-1}}{P_{t-1}}$

\section{JENIS DAN SUMBER DATA}

Data yang digunakan dalam penelitian ini adalah data sekunder dan 
Nurhidayati, et al/Jurnal Ekonomi Syariah Teori dan Terapan Vol. 6 No. 2 Februari 2019: 214-227;

PENGARUH FAKTOR MAKROEKONOMI DAN FAKTOR FUNDAMENTAL TERHADAP RETURN SAHAM PERUSAHAAN YANG LISTING DI JAKARTA ISLAMIC INDEX PERIODE 2012-2016

termasuk data time series. Data pada penelitian ini diperoleh dari statistik laporan keuangan yang diterbitkan di idx.co.id yang diambil periode 2012 hingga 2016

\section{POPULASI DAN SAMPEL}

Populasi dalam penelitian ini adalah perusahaan di Jakarta Islamic Index sedangkan sampel dalam penelitian ini adalah sampel 20 data secara tahunan dengan periode 2012 hingga 2016. Metode pemilihan sampel yang digunakan dalam penelitian ini adalah metode pemilihan secara purposive sampling.

\section{TEKNIK ANALISIS}

Teknik analisis regresi data panel untuk melihat data menggunakan penggabungan time series dan cross section memiliki keunggulan daripada hanya menggunakan data time series dan cross section

\section{Estimasi Regresi Data Panel}

Uji ini dilakukan untuk dalam mengistimasi data panel terdapat tiga pendekatan yang biasa dilakukan, yaitu model OLS pooled/Common Effect Model (CEM), Fixed Effect Model (FEM) dan Random Effect Model (REM)

1. OLS Pooled / Common Effect Model (CEM)

Teknik yang paling sederhana untuk mengestimasi data panel hanya dengan mengkombinasikan data time series dan cross section. Dengan hanya menggabungkan data tersebut tanpa melihat perbedaan antar waktu dan individu, maka dapat menggunakan metode OLS untuk mengestimasi model data panel

$$
\mathrm{Y}_{\mathrm{it}}=\alpha+\beta_{1} \mathrm{X}_{1 \text { it }}+\beta_{2} \mathrm{X}_{2} \text { it }+\beta_{3} \mathrm{X}_{3} \text { it }+\varepsilon \text { it }
$$

2. Fixed Effect Model (FEM)

Teknik model fixed effect adalah teknik mengestimasi data panel dengan menggunakan variabel dummy untuk menangkap adanya perbedaan intersep. Model ini mengasumsikan bahwa intersep adalah berbeda setiap subyek, sedangkan slope tetap sama antar subyek. Dalam membedakan satu subyek dengan subyek lainnya digunakan variabel dummy.

$Y_{\text {it }}=\alpha+\beta_{1} X_{\text {lit }}+\beta_{1} X_{\text {lit }}+\beta_{1} X_{\text {lit }}+\beta_{1} X_{\text {lit }}+\beta_{1} X_{\text {lit }}+\varepsilon_{\text {it }}$

3. Random Effect Model (REM)

Model ini mengestimasi data panel dimana variabel gangguan mungkin saling berhubungan antar waktu dan antar inidividu dan diasumsikan setiap subjek penelitan memiliki perbedaan intersep.

$$
\mathrm{y}_{\text {it }}=\beta_{1}+\beta_{2} \mathrm{X}_{2 \mathrm{it}}+\ldots+\beta_{n} \mathrm{X}_{\text {nit }}=\mathrm{w}_{\mathrm{it}}
$$

\section{Uji † Statistik}

Uji $†$ adalah pengujian terhadap koefisien dari variabel bebas secara parsial. Uji ini dilakukan untuk membuktikan apakah variabel independen secara individu mempengaruhi variabel dependen. Pengujian dilakukan dengan 
Nurhidayati, et al/Jurnal Ekonomi Syariah Teori dan Terapan Vol. 6 No. 2 Februari 2019: 214-227; PENGARUH FAKTOR MAKROEKONOMI DAN FAKTOR FUNDAMENTAL TERHADAP RETURN SAHAM PERUSAHAAN YANG LISTING DI JAKARTA ISLAMIC INDEX PERIODE 2012-2016

menggunakan significance level 0,05 $(a=5 \%)$

\section{Uji F-Statistik}

Uji $F$ adalah pengujian model secara keseluruhan. Oleh karena itu, uji $F$ ini lebih relevan dilakukan pada regresi berganda. Uji $F$ dilakukan untuk mengevaluasi pengaruh variabel bebas terhadap variabel terikat secara bersamasama. Pengujian dilakukan dengan menggunakan significance level 0,05 $(a=5 \%)$.

\section{Uji R² (R-Square)}

Koefisien determinasi

digunakan untuk mengatur seberapa baik garis regresi sesuai dengan data aktualnya (goodness of fit). Selain itu, pengujian ini digunakan untuk mengukur seberapa besar persentase variabel independennya dengan melihat nilai R2 (R-square) dari hasil estimasi. Koefisien determinasi ini mengukur prosentase total variasi variabel dependen $Y$ yang dijelaskan oleh variabel dependen di dalam garis regresi. Koefisien determinasi (R2) semakin mendekati 1 maka semakin baik garis regresi dan semakin mendekati nol maka kita mempunyai garis regresi yang kurang baik.

\section{HASIL \\ PENELITIAN \\ PEMBAHASAN \\ Pemilihan Model Estimasi Data Panel \\ UJI Chow}

DAN

Hasil uji Chow ditunjkkan oleh tabel
Tabel 1.

UJI Chow

Redundant Fixed Effects Tests Pool: Untitled

Test cross-section fixed effects

\begin{tabular}{lrrr}
\hline \hline Effects Test & Statistic & d.f. & Prob. \\
\hline \hline Cross-section F & 1.037743 & $(19,73)$ & 0.4313 \\
Cross-section Chi-square & 23.909372 & 19 & 0.1997 \\
\hline \hline
\end{tabular}

Berdasarkan hasil Uji Chow pada Tabel 1 diatas menunjukkan nilai probabilitas Cross-Section $F$ adalah sebesar 0.4313 lebih besar dari tingkat signifikansi $5 \%(a=0,05)$. Maka dapat disimpulkan bahwa $\mathrm{HO}$ diterima dan $\mathrm{Hl}$ ditolak, sehingga model yang terbaik menggunakan Common Effect Model (CEM).

\section{Uji Hipotesis}

Hasil uji Common Effect Model akan ditunjukkan oleh gambar berikut

\section{Tabel 2.}

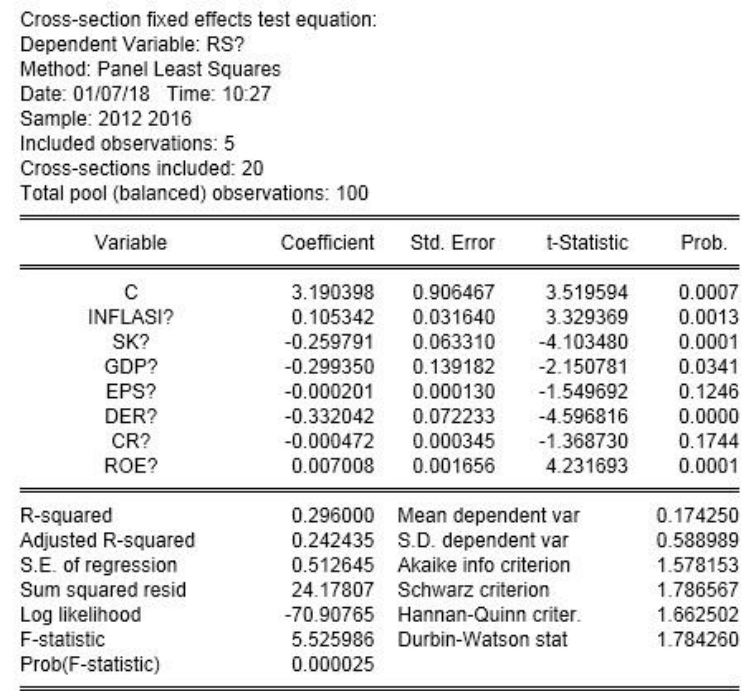

Berdasarkan hasil pengujian

analisis regresi data panel pada Tabel 4 diatas, maka dapat disusun persamaan model regresi sebagai berikut :

ReturnSaham $_{\text {it }}=3,190398+0,0013$ Inflasi $_{\text {it }}+0,0001$ BiRate $_{\text {it }}+0,0341 \mathrm{GDP}_{\text {it }}+$ $0,1246 \mathrm{EPS}_{\mathrm{it}}+0,0000 \mathrm{DER}_{\mathrm{it}}+0,1744 \mathrm{CR}_{\mathrm{it}}+0,0001 \mathrm{ROE}_{\mathrm{it}}$ 
Nurhidayati, et al/Jurnal Ekonomi Syariah Teori dan Terapan Vol. 6 No. 2 Februari 2019: 214-227;

PENGARUH FAKTOR MAKROEKONOMI DAN FAKTOR FUNDAMENTAL TERHADAP RETURN SAHAM PERUSAHAAN YANG LISTING DI JAKARTA ISLAMIC INDEX PERIODE 2012-2016

\section{Uji Parsial ( t-test)}

Uji parsial (Uji t) digunakan untuk menguji dan membuktikan apakah masing-masing variabel independen secara individu mempengaruhi variabel dependen.

$\mathrm{H}_{0}=$ Variabel independen secara parsial berpengaruh tidak signifikan terhadap variabel dependen

$\mathrm{H}_{1}=$ Variabel independen secara parsial berpengaruh signifikan terhadap variable dependen

Kriteria dalam penerimaan $\mathrm{HO}$ dan $\mathrm{HI}$ adalah dengan melihat nilai probabilitas (p-value) dari masing-masing variabel. Jika nilai probabilitas lebih kecil dari 0,05 (taraf kepercayaan 95\%) maka HO ditolak dan $\mathrm{Hl}$ diterima Begitu juga sebaliknya. Maka hasil uji $\dagger$ dapat diambil keputusan hipotesis sebagai berikut:

1. Nilai konstanta sebesar 3,190398 menunjukkan apabila variabel Inflasi, Bi Rate, Gross Domestic Product(GDP), Earning Per Share (EPS), Current Ratio (CR), Debt to Equity Ratio (DER), dan Return On Equity Ratio (ROE) besarnya nol atau konstan, makla nilai beta saham adalah sebesar 3,190398.

2. Variabel Inflasi memiliki nilai probabilitas sebesar $\quad 0,0013$ signifikan pada tingkat signifikansi $5 \%$ sehingga $\mathrm{Hl}$ diterima dan $\mathrm{HO}$ ditolak. .Hal ini menunjukkan bahwa Inflasi memiliki pengaruh signifikan terhadap return Saham.

3. Variabel Bi Rate memiliki nilai probabilitas sebesar 0,0001 lebih kecil dari tingkat signifikansi $5 \%$ $(a=0,05)$ sehingga $\mathrm{HO}$ ditolak dan H2 diterima. Hal ini menunjukkan terdapat pengaruh signifikan antara terhadap return Saham

4. Variabel Gross Domestic Product (GDP) memiliki nilai probabilitas sebesar 0,0341 signifikan pada tingkat signifikansi $5 \%$ sehingga $\mathrm{HO}$ ditolak dan H3 diterima. Hal ini menunjukkan bahwa Gross Domestic Product (GDP) memiliki pengaruh tidak signifikan terhadap return Saham.

5. Variabel Earning Per Share (EPS) memiliki nilai probabilitas sebesar 0,1246 tidak signifikan pada tingkat signifikansi $5 \%$ sehingga $\mathrm{HO}$ diterima dan $\mathrm{H} 4$ ditolak. Hal ini menunjukkan bahwa Earning Per Share (EPS) memiliki pengaruh tidak signifikan terhadap return Saham.

6. Variabel Debt to Equity Ratio (DER) memiliki nilai probabilitas sebesar 0,000 signifikan pada tingkat signifikansi $5 \%$ sehingga $\mathrm{HO}$ ditolak dan H5 diterima. Hal ini menunjukkan bahwa Debt to Equity Ratio (DER) memiliki pengaruh signifikan terhadap return Saham.

7. Variabel Current Ratio (CR) memiliki nilai probabilitas sebesar 0,1744 tidak signifikan pada tingkat signifikansi $5 \%$ sehingga $\mathrm{HO}$ diterima dan $\mathrm{H} 6$ ditolak. Hal ini menunjukkan bahwa Current Ratio 
Nurhidayati, et al/Jurnal Ekonomi Syariah Teori dan Terapan Vol. 6 No. 2 Februari 2019: 214-227; PENGARUH FAKTOR MAKROEKONOMI DAN FAKTOR FUNDAMENTAL TERHADAP RETURN SAHAM PERUSAHAAN YANG LISTING DI JAKARTA ISLAMIC INDEX PERIODE 2012-2016

(CR) memiliki pengaruh tidak signifikan terhadap return Saham.

8. Variabel Return On Equity (ROE) memiliki nilai probabilitas sebesar 0,0001 signifikan pada tingkat signifikansi $5 \%$ sehingga $\mathrm{HO}$ ditolak dan H7 diterima. Hal ini menunjukkan bahwa Return On Equity (ROE) memiliki pengaruh signifikan terhadap return Saham.

Uji Simultan (F-test)

Berdasarkan hasil pengujian dengan model terbaik yaitu Common Effect Model (CEM) pada Tabel 4 diatas, dapat dilihat bahwa nilai probabilitas Fstatistic adalah sebesar 0,000025, nilai ini lebih kecil dari 0,05 dan signifikan pada tingkat kepercayaan 95\% (a = 0,05), sehingga $\mathrm{HO}$ ditolak dan $\mathrm{Hl}$ diterima. Maka dapat disimpulkan bahwa variabel independen, Inflasi, Bi Rate, Gross Domestic Product(GDP), Earning Per Share (EPS), Current Ratio (CR), Debt to Equity Ratio (DER), dan Return On Equity Ratio (ROE) secara bersama-sama (simultan) berpengaruh signifikan terhadap variabel dependen, yaitu return saham.

\section{Analisis Koefisien Determinasi ( $\left.\mathbf{R}^{2}\right)$}

Uji koefisien Determinasi (R2) bertujuan untuk mengetahui seberapa besar variabel independen pada model regresi dapat menjelaskan variabel dependennya. Berdasarkan hasil pengujian statistik dengan model terbaik yaitu Common Effect Model (CEM) yang disajikan pada Tabel 4.10 diatas maka diperoleh nilai Adjusted R-Squared sebesar 0,242435 . Sehingga dapat disimpulkan bahwa variabel independen yaitu Inflasi, Bi Rate, Gross Domestic Product(GDP), Earning Per Share (EPS), Current Ratio (CR), Debt to Equity Ratio (DER), dan Return On Equity Ratio (ROE) hanya dapat menjelaskan $24,24 \%$ variabel dependen yaitu return saham perusahaan Jakarta Islamic Index periode 2012-2016 dan sisanya $75,76 \%$ dipengaruhi oleh faktorfaktor lain yang tidak digunakan dalam model regresi pada penelitian ini.

\section{PEMBAHASAN}

Pengaruh secara Parsial Inflasi terhadap Return Saham

Pengaruh secara parsial (uji t) dengan menggunakan a sebesar $5 \%$, diperoleh hasil bahwa probabilitas variabel Inflasi lebih kecil daripada a $(0.13 \%>5 \%)$. Hal ini berarti bahwa variabel Inflasi memiliki pengaruh positif dan signifikan terhadap return saham perusahaan.

\section{Pengaruh secara Parsial Bi Rate terhadap}

\section{Return Saham}

pengaruh secara parsial (uji t) dengan menggunakan a sebesar $5 \%$, diperoleh hasil bahwa probabilitas variabel Return On Equity ratio lebih kecil daripada a $(0,01 \%>5 \%)$. Hal ini berarti bahwa variabel Return On Equity memiliki pengaruh negatif dan signifikan terhadap return saham perusahaan.

\section{Pengaruh secara Parsial Gross Domestic} Product terhadap Return Saham

Pengaruh secara parsial (uji †) dengan menggunakan a sebesar $5 \%$, diperoleh hasil bahwa probabilitas variabel Gross Domestic Product lebih kecil daripada a $(3,41 \%<5 \%)$. Hal ini berarti bahwa 
Nurhidayati, et al/Jurnal Ekonomi Syariah Teori dan Terapan Vol. 6 No. 2 Februari 2019: 214-227; PENGARUH FAKTOR MAKROEKONOMI DAN FAKTOR FUNDAMENTAL TERHADAP RETURN SAHAM PERUSAHAAN YANG LISTING DI JAKARTA ISLAMIC INDEX PERIODE 2012-2016

variabel profitabilitas memiliki pengaruh negatif dan signifikan terhadap return saham perusahaan.

Pengaruh secara secara Earning Per Share terhadap Return Saham

Pengaruh secara parsial (uji t) dengan menggunakan a sebesar $5 \%$, diperoleh hasil bahwa probabilitas variabel Earning Per Share lebih besar 0,1246 daripada a $(12,46 \%<5 \%)$. Hal ini berarti bahwa variabel Earning Per Share memiliki pengaruh negatif dan tidak signifikan terhadap return saham perusahaan.

Earning Per Share merupakan rasio untuk mengetahui tingkat keuntungan yang diperoleh investor per saham. Jika Earning Per Share meningkat maka return yang akan di dapat meningkat pula, dan investor akan semakin tertarik pada perusahaan tersebut karena kemampuan perusahaan memberikan tingkat return yang tinggi. Dengan nilai return yang semakin tinggi belum tentu return saham yang diterima oleh investor juga tinggi, karena terdapat faktor lain yang dapat mempengaruhi return saham yaitu faktor makro dan faktor pasar.

Pengaruh secara secara Debt to Equity terhadap Return Saham

Pengaruh secara parsial (uji t) dengan menggunakan a sebesar $5 \%$, diperoleh hasil bahwa probabilitas variabel Debt to Equity Ratio lebih kecil daripada a $(0 \%<5 \%)$. Hal ini berarti bahwa variabel Debt to Equity Ratio memiliki pengaruh negatif dan signifikan terhadap return saham perusahaan.
Pengaruh secara secara Current Ratio terhadap Return Saham

Pengaruh secara parsial (uji t) dengan menggunakan a sebesar $5 \%$, diperoleh hasil bahwa probabilitas variabel Current Ratio lebih besar 0,1744 daripada a $(17,44 \%<5 \%)$. Hal ini berarti bahwa variabel Current Ratio memiliki pengaruh negatif dan tidak signifikan terhadap return saham perusahaan.

Current ratio merupakan rasio untuk mengetahui kemampuan perusahaan terhadap likuiditas atau kewajiban lancarnya. Jika likuiditas tinggi maka aktiva lancarnya tidak digunakan secara optimal, maka ada kecenderungan dividen menururn dan return saham pun menurun.

Pengaruh secara secara Return On Equity terhadap Return Saham

Pengaruh secara parsial (uji t) dengan menggunakan a sebesar 5\%, diperoleh hasil bahwa probabilitas variable Return On Equity lebih kecil daripada a $0,01 \%<$ $5 \%)$. Hal ini berarti bahwa variabel profitabilitas memiliki pengaruh positif dan signifikan terhadap return saham perusahaan.

\section{v. SIMPULAN}

Berdasarkan hasil analisis dan pembahasan pada bab sebelumnya, maka dapat disimpulkan sebagai berikut :

1. Inflasi dan Return On Equity ratio secara parsial bepengaruh signifikan terhadap return saham perusahaan yang Isiting Jakarta Islamic Index tahun 2012-2016. 
Nurhidayati, et al/Jurnal Ekonomi Syariah Teori dan Terapan Vol. 6 No. 2 Februari 2019: 214-227; PENGARUH FAKTOR MAKROEKONOMI DAN FAKTOR FUNDAMENTAL TERHADAP RETURN SAHAM PERUSAHAAN YANG LISTING DI JAKARTA ISLAMIC INDEX PERIODE 2012-2016

2. Earning Per Share dan Current Ratio secara parsial bepengaruh negative dan tidak signifikan terhadap return saham perusahaan yang listing di Jakarta Islamic Index tahun 2012-2016.

3. Inflasi, Bi Rate, Gross Domestics Product, Earning Per Share (EPS), Current Ratio (CR), Debt to Equity ratio (DER), dan Return on Equity (ROE), secara simultan berpengaruh signifikan terhadap return saham perusahaan yang listing Jakarta Islamic Index tahun 2012-2016, pada tingkat signifikansi $5 \%(a=0,05)$.

Saran yang dapat diberikan dari penelitian ini adalah:

1. Bagi Emiten

Pada emiten atau perusahaan sebaiknya menguatkan dan menjaga rasio-rasio kevangan di perusahaan, karena laporan keuangan merupakan sebuah bentuk kondisi dan informasi suatu perusahaan. Hal ini dapat menarik minat investor karena dapat memperkuat posisi neraca keuangan perusahaan.

2. Bagi investor

Bagi penanam modal atau investor yang ingin penyaluran returnnya tinggi dan ingin mempunyai resiko yang stabil pada factor eksternal dan internalnya, oleh karena itu disarankan untuk menanamkan modalnya dalam perusahaan yang terikat dalam Jakarta Islamic Index (JII) karena termasuk dalam kriteria syariah dimana kegiatan operasional perusahaan sesuai dengan peraturan yang ditetapkan oleh DSN-MUI dan Bapepam-LK.

3. Bagi penelitian selanjutnya Pada penelitian yang di teliti ini diharapkan dapat dijadikan sebagai referensi bagi penelitian selanjutnya sehingga saran yang dapat diberikan adalah:

a. Menggunakan variabel yang lain dalam meneliti pengaruh variabel-variabel terhadap return. Bisa menjadi sebagai bahan referensi untuk penelitian selanjutnya.

b. Subjek pada penelitian ini adalah perusahaan yang listing di Jakarta Islamic Index yang terdapat 30 perusahaan selama periode tahun 2012-2016 sesuai dengan kriteria. Untuk penelitian selanjutnya bisa memilih saham syariah yang dan non saham syariah atau menggunakan emiten atau perusahaan yang terdaftar di Daftar Efek Syariah (DES) atau menggunakan emiten yang terdaftar di Indeks Saham Syariah Indonesia (ISSI). 
Nurhidayati, et al/Jurnal Ekonomi Syariah Teori dan Terapan Vol. 6 No. 2 Februari 2019: 214-227;

PENGARUH FAKTOR MAKROEKONOMI DAN FAKTOR FUNDAMENTAL TERHADAP RETURN SAHAM

PERUSAHAAN YANG LISTING DI JAKARTA ISLAMIC INDEX PERIODE 2012-2016

\section{DAFTAR PUSTAKA}

Agnes, Sawir, 2009. Analisa Kinerja dan Perencanaan Kevangan

Perusahaan, Jakarta; PT. Gramedia Pustaka Utama.

Anatasia, Njo dan Imelda wijayanti. 2003. Analisis Faktor Fundamental Dan Risiko Sistematik.

Ang, Robert .1997. Pasar Modal Indonesia: Media Soft Indonesia.

Brigham, Eugene F. dan Gapenski, Louis C. 1997. Financial Management Theory and Practice. Orlando: The Dryden Press.

Boediono. 2009. Teori Pertumbuhan

Ekonomi. Yogyakarta : BPFE UGM.

Gumandi, T. A. 2011 . Manajemen Investasi. Jakarta: Mitra Wacana Media.

Hery, S.E., M.Si, "Analisis Laporan Keuangan", (Center for Academic Publishing Service; Yogyakarta, thn 2015), hlm 29.

Herlambang, T. 2001. Ekonomi Makro: Teori, Analisa, dan Kebijakan. Jakarta: Gramedia Pustaka Utama. Hartono, Jogiyanto, 1998, Teori Portofolio dan Analisis Investasi. Edisi pertama. BPFE. Yogyakarta.

A Helfert, Erich. 2002. Teknik Analisis Keunagan. Jakarta, Penerbit Airlangga.

Liauw, Joven Sugianto. 2013. Analisis Pengaruh Inflasi, SBI, Nilai Tukar terhadap Indeks Saham Gabungan. Jurnal IImiah. STIE MDP, 2013.

Mankiw, N.Gregory, 2007. Makroekonomi. Edisi keenam. Jakarta: Erlangga.
Samsul, Mohammad. 2006. Pasar Modal dan Manajemen Portofolio. Surabaya: Erlangga.

Suhartono dan Qudsi, Fadillah, 2009. "Portofolio Investasi dan Bursa Efek Pendekatan Teori dan Praktik",Yogyakarta, UPP STIM YKPN.

Susilo D, Bambang, 2009. "Pasar Modal". Yogyakarta: UPP STIM YKPN Yogyakarta.

Tandelilin, Eduardus. 2010. Portofolio dan Investasi: Teori dan Aplikasi. Edisi Pertama. Yogyakarta: KANISIUS. 